\title{
Tonsillar Capsule
}

National Cancer Institute

\section{Source}

National Cancer Institute. Tonsillar Capsule. NCI Thesaurus. Code C49788.

A thick, fibrous, partial capsule of dense connective tissue on the outer aspect of the palatine tonsil that anteroinferiorly adheres to the side of the tongue and forms its lateral boundary with the oropharyngeal wall. 